\title{
CHANGES IN GLUTATHIONE SYSTEM AND LIPID PEROXIDATION IN RAT BLOOD DURING THE FIRST HOUR AFTER CHLORPYRIFOS EXPOSURE
}

\author{
V. P. ROSALOVSKY, S. V. GRABOVSKA, Yu. T. SALYHA \\ Institute of Animal Biology, National Academy of Agrarian Sciences of Ukraine, Lviv; \\ e-mail: ros.volodymyr@gmail.com
}

\begin{abstract}
Chlorpyrifos (CPF) is a highly toxic organophosphate compound, widely used as an active substance of many insecticides. Along with the anticholinesterase action, CPF may affect other biochemical mechanisms, particularly through disrupting pro- and antioxidant balance and inducing free-radical oxidative stress. Origins and occurrence of these phenomena are still not fully understood. The aim of our work was to investigate the effects of chlorpyrifos on key parameters of glutathione system and on lipid peroxidation in rat blood in the time dynamics during one hour after exposure. We found that a single exposure to $50 \mathrm{mg} / \mathrm{kg}$ chlorpyrifos caused a linear decrease in butyryl cholinesterase activity, increased activity of glutathione peroxidase and glutathione reductase, alterations in the levels of glutathione, TBA-active products and lipid hydroperoxides during 1 hour after poisoning. The most significant changes in studied parameters were detected at the 15-30 ${ }^{\text {th }}$ minutes after chlorpyrifos exposure.
\end{abstract}

Key words: antioxidant defense system, glutathione system, glutathione peroxidase, glutathione reductase, reduced glutathione, lipid peroxidation, blood, chlorpyrifos, rats.

$\mathrm{O}$ rganophosphates (OPs) are the main active substances in many pesticides and household chemicals; they are also used in the chemical industry, medicine, etc. High toxicity of the OPs causes considerable risk of intoxication. Chlorpyrifos (CPF) is one of the most common and hazardous of these compounds. CPF (O,O-diethyl O-3,5,6-trichloropyridin-2-yl phosphorothioate $\left.\left(\mathrm{C}_{9} \mathrm{H}_{11} \mathrm{Cl}_{3} \mathrm{NO}_{3} \mathrm{PS}\right)\right)$ is known as the active ingredient of many common broad-spectrum insecticides [1, 2].

The main biochemical mechanism of CPF toxicity is inhibition of cholinesterase enzymes, causing disruption of synaptic transmission. Till recently, this was considered as a key and almost only toxicity mechanism of CPF, and all OPs in general, but the latest studies have convincingly shown that the toxic effect of OPs is more complex and is not limited to anticholinergic action [2, 4]. Besides cholinesterases, other potential molecular targets of OPs were found [2-4]. In particular, in vitro studies have shown cytotoxicity of CPF and its effects on the synthesis of macromolecules (DNA, RNA, proteins) and differentiation of neurons, possible interaction with neurotransmitter receptors and various enzymes, other neurochemical effects (e.g., influence on neurotransmitter release or uptake) [4-6]. CPF also disrupts the endocrine actions of androgenic, estrogenic, thyroid and parathyroid hormones [7]. Special attention is required to the fact that free radical oxidation, a universal pathophysiological phenomenon in many pathological conditions, also plays a significant role in response to toxic effects of various xenobiotics, including OPs and CPF in particular [4, 8]. A number of works, including our previous studies, have shown that CPF may also induce oxidative stress, which itself is a significant toxicity factor and can lead to generation of free radicals and alteration in antioxidant system functioning and scavenging of free oxygen radicals $[4,6]$. Oxidative stress is characterized by excessive formation of reactive oxygen species (ROS), leading to lipid peroxidation syndrome, which includes such pathological components as disruption of cell division and phagocytosis, structural and functional changes in the membrane.

It should be stressed that biological mechanisms of CPF induced the oxidative stress; its characteristics and consequences are complex and directly or indirectly affect a variety of related metabolic pathways. In particular, Cytochrome P450 (CY P450) converts CPF into chlorpyrifos oxon, which is splitted by $\alpha$-esterases, for example paraoxonase, and is further converted to diethyl 
phosphate and 3,5,6-trichloro-2-pyridinol by the CYP450 system [9]. Paraoxonase (PON), which has 3 isoforms - PON1, PON2 and PON3, is a calciumdependent enzyme with varied substrates. It can hydrolyze paraoxon and exhibit arylesterase and thiolactonase activity. Importantly, besides the fact that PON1 is a first phase enzyme that is involved in the hydrolysis of OP esters including CPF, this enzyme has also antioxidant properties and prevents oxidative modifications of lipoproteins apart from hydrolyzing oxidized phospholipids, hydroperoxides and lactones [9, 10].

Glutathione peroxidase (GPO), glutathione reductase (GR), and the non-enzymatic component, reduced glutathione (GSH) constitute the glutathione antioxidant defense system. Study of its functioning under the toxic effect of CPF is important because the glutathione system is known to participate in a list of biochemical detoxification mechanisms of lipophilic and hydrophilic xenobiotics. Glutathione is the primary defense agent against oxidative stress in erythrocytes, and its adequate levels are essential for maintaining the natural conformation of hemoglobin [11]. Optimal glutathione levels in erythrocytes are therefore critical in minimizing the damaging effects of ROS and autoxidation of hemoglobin in the cytosol [12]. In conditions of chronic oxidative stress oxidized glutathione (GSSG) is expelled from the cell by virtue of membrane transporters and increased membrane permeability [11, 13]. The role of gluthatione in the biotransformation and detoxification of xenobiotics greatly determines the organism's resistance to their toxicity. Protective properties of the glutathione system are conferred by the actions of GST and GPO. Also, the glutathione system is the primary protector of mitochondrial and cell membranes against oxidative damage [12].

It should be emphasized that among all tissues and structures of the body the red blood cells play the major role as free radical scavengers and are continuously exposed to ROS in the systemic circulation and the autoxidation of hemoglobin in the cytosol $[12,14]$. The plasma membranes of red blood cells are very sensitive to damage by oxidative stress because of very high percentage of unsaturated lipids, which underlie their considerable flexibility [12]. The progressively increasing oxidative stress causes changes in the primary structure and functions of hemoglobin, which may lead to hemolysis [11].

The membrane lipids, which undergo peroxidation (LPO), are among the most vulnerable targets of ROS. Thus, the assessment of LPO processes has also been successfully employed to signify oxidative stress induced in animals by OP chemicals.

Therefore, despite the fact that oxidative stress induction by $\mathrm{CPF}$ is proven, many questions remain unanswered in this field. One of the major tasks is to elucidate biochemical parameters of the glutathione system and LPO at different time intervals after the CPF exposure. It is very important to figure out how these biochemical processes are performed in the animal blood immediately after, and during first minutes after organophosphate poisoning.

Consequently, the aim of this study was to investigate changes in some enzymatic (GPO and GR activity) and non-enzymatic (amount of GSH, lipid hydroperoxides, thiobarbituric acid reactive substances (TBARS)) parameters of the red blood cell antioxidant defence system during the first hour after CPF intoxication, in dynamics: 15, 30, 45 and $60 \mathrm{~min}$ after CPF exposure to rats.

\section{Materials and Methods}

The study was conducted on 40 adult male white Wistar rats of 200-220 g body weight. Rats were housed under standardized laboratory conditions, with $12 \mathrm{~h}$ dark/light cycle and free access to food and tab water ad libitum. All procedures were conducted according to the European Convention for the Protection of Vertebrate Animals used for Experimental and Other Scientific Purposes (Strasbourg, 1986) and General Ethical Principles of Experiments using Animals (First National Congress of Bioethics, Kyiv, 2001).

The animals were randomly divided into 8 groups: 4 control (C1, C2, C3, C4) and 4 experimental (E1, E2, E3, E4) groups, each comprising 5 animals. Rats of experimental groups were exposed to $\mathrm{CPF}$ in a dose of $50 \mathrm{mg} / \mathrm{kg}$ of body weight intragastrically via an oral probe. CPF was diluted in sunflower oil. Intact animals of control groups received the equivalent amount of pure oil.

At the end of the experimental period, the rats were sacrificed by decapitation (15 min (groups $\mathrm{C} 1$ and E1), 30 min (C2 and E2), 45 min (C3 and E3), and 60 (C4 and $\mathrm{E} 4$ ) min after the exposure, to obtain samples of peripheral blood.

For biochemical studies, heparinised blood samples were centrifuged for $15 \mathrm{~min}$ at $1500 \mathrm{~g}$. After plasma separation, erythrocytes were washed three times with $0.9 \% \mathrm{NaCl}$. Hemolysate was obtained by three-time freezing-thawing of red blood cells aque- 
ous suspensions and their subsequent centrifugation at $10700 \mathrm{~g}$ for $15 \mathrm{~min}$.

Blood serum butyryl cholinesterase (BuChE) (EC 3.1.1.8) activity was measured by Karpyshtshenko [15], using the commercial kit by Filicit-Diagnostics (Ukraine). The optical density was measured spectrophotometrically at a wavelength of $540 \mathrm{~nm}$ against distilled water.

GPO (glutathione hydrogen-peroxide oxidoreductase, EC 1.11.1.9) activity was studied by measuring the tempo of GSH oxidation before and after incubation with tertiary butyl hydroperoxide. The color reaction is based on the interaction of SH-groups with the 5,5-dytiobis-2-nitrobenzoic acid (DTNBA), resulting in the formation of colored product - dinitrophenyl anion [16]. Quantity of the latter is directly proportional to the number of $\mathrm{SH}$-groups that have reacted with DTNBA. Enzyme activity was expressed as nmol GSH/min'mg of protein.

GR (glutathione $\mathrm{NADP}^{+}$oxidoreductase, EC 1.6.4.2) activity was measured by Carlberg [17]. This method is based on the catalytic NADPHdependent reduction of the oxidized form of glutathione. The reaction intensity can be assessed by the tempo of decrease of the extinction on the wavelength of NADPH maximum absorption $(340 \mathrm{~nm})$. GR activity was calculated using molar absorption ratio for NADPH at a wavelength of $340 \mathrm{~nm}$ $\left(\dot{\varepsilon}=6200 \mathrm{M}^{-1} \mathrm{~cm}^{-1}\right)$. The enzyme activity was expressed in $\mathrm{mmol} \mathrm{NADPH} / \mathrm{min} \cdot \mathrm{mg}$ of protein.

GSH level was colorimetrically measured before and after the reaction, by Hissin [18]. This colour reaction is based on the interaction between SH-groups and DTNBA. GSH content was measured using the calibration graph and expressed in $\mathrm{mmol} / \mathrm{g}$ of protein.

The content of lipid hydroperoxides in erythrocyte mass was determined by [19]. This method is based on spectrophotometrical optical density measurement of the products of ammonium thiocyanate, hydrochloric acid and Mohr salt reaction. Lipids from the samples were preliminarily extracted with ethanol. Selection of tissue samples and preparation for extraction were performed at $4{ }^{\circ} \mathrm{C}$. Ethanol $(2.8 \mathrm{ml})$ and $0.05 \mathrm{ml}$ of $50 \%$ trichloroacetic acid (TCA) were added to $0.2 \mathrm{ml}$ of hemolisate (dissolved in buffer solution with $\mathrm{pH}$ 7.4), and shaken for 5-6 min. Obtained protein precipitate was separated by centrifugation at $700 \mathrm{~g}$. Ethanol $(1.2 \mathrm{ml}), 0.02 \mathrm{ml}$ of concentrated $\mathrm{HCl}$, and $0.03 \mathrm{ml}$ of $1 \%$ Mohr salt solution in $3 \% \mathrm{HCl}$ were added to $1.5 \mathrm{ml}$ of super- natant. The mixture was stirred. After $30 \mathrm{~s}, 0.2 \mathrm{ml}$ of $20 \%$ ammonium thiocyanate was added, and then the absorbance of the solution was determined at $\lambda=480 \mathrm{~nm}$. In a control sample, the appropriate amount of bidistilled water was added instead of supernatant. The content of lipid hydroperoxides was calculated by the difference between experimental and control values, and expressed in arbitrary units of optical density for $1 \mathrm{~g}$ of tissue.

The concentration of TBARS, characterizing the LPO rate, was assessed by Korobeinikova, based on the reaction between malondialdehyde (MDA) and thiobarbituric acid (TBA), occurring at high temperature and in acidic environment, and forming the colored complex of one MDA and two TBA molecules [20]. [21].

Protein concentration was measured by Lowry

All reagents used were obtained from SigmaAldrich and Fluka (USA).

The experimental data were processed by variation statistics methods using the program OriginPro 8. Student t-test was used to determine the likely differences between the means of the samples. In all cases, reliable differences were considered by $P$ value under 5\% $(P<0.05)$.

\section{Results and Discussion}

Poisoning by OPs leads to cholinesterase phosphorylation, producing phosphorylated cholinesterase (cholinesterase + OP residue containing phosphorus in the form of phosphoric acid residue), that loses its ability to hydrolyze acetylcholine and regains its function very slowly. It is known that BuChE, or pseudocholinesterase, is common for blood serum. It is produced by hepatocytes and splits not only acetylcholine, but also other choline compounds. BuChE has a protective function, preventing the inactivation of acetylcholinesterase (AChE) by a high-speed hydrolization of its inhibitor - butyryl choline. As cholinesterases activity is a common indicator of the severity of OP intoxication, determination of BuChE activity was used in our study.

The BuChE activity in rat blood serum 15, 30, 45 and 60 min after CPF exposure is presented on Fig. 1. All experimental groups showed a significant $P<0.05)$ decrease in BuChE activity by $42.5 \%$ (E1), $65.5 \%$ (E2), $81.1 \%$ (E3), 54.6\% (E4), compared to control groups of intact animals. Therefore, during the first $45 \mathrm{~min}$, a rapid and almost linear decline in enzymatic activity was detected. 


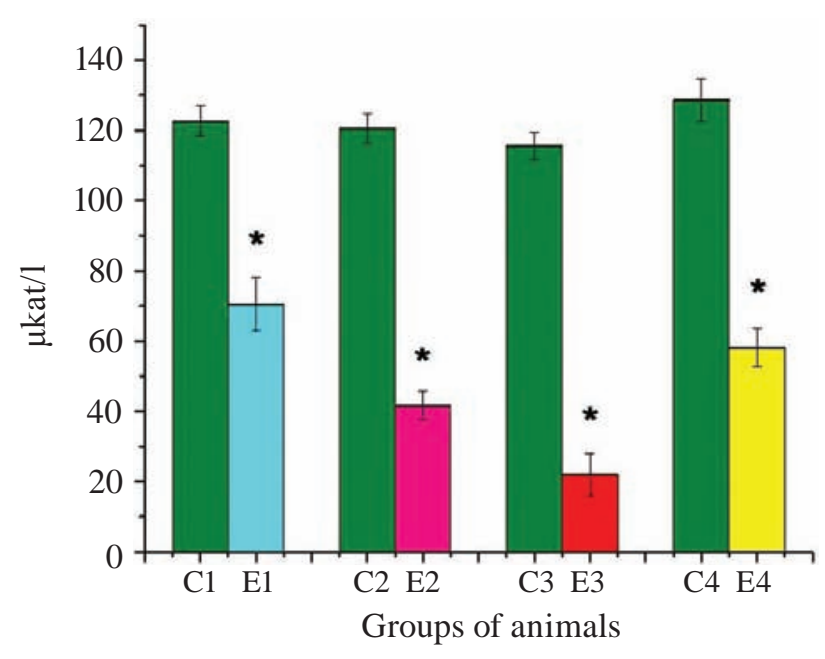

Fig. 1. BuChE activity in blood serum of different groups of rats exposed to CPF. Here and later: C1, C2, C3, C4 - groups of intact animals, E1, E2, E3, E4 - groups of experimental animals. Data are means \pm SEM, $n=5$. * Significantly different from the respective control group with $P<0.05$

But in an hour after CPF exposure, the activity rose from its minimum values and almost reached the rates of E1 group. Nevertheless, even despite such an increase, compared to E2 and E3 groups, it remained more than 2 times lower than in the control group. Such alterations in BuChE activity indicate acute poisoning of the experimental rats that became more severe till the $45^{\text {th }}$ minute after CPF exposure. Serum BuChE inhibition leads to acetylcholine increase in blood, which affects endothelium via stimulation of M-receptors and intracellular calcium and generation of nitrogen oxide. This causes endothelium damage and impaired microcirculation. Functional alterations in microcirculation, in their turn, may serve as important factors in etiology of OP intoxication consequences. It also should be stressed that irreversible cholinesterase inhibition caused by OPs, and particularly CPF, induces acetylcholine accumulation, resulting in overstimulation of M- and N-cholinereactive systems. Acute intoxication leads to a variety of different consequences: one of the most dangerous is a rapid decline in blood pressure, which ultimately causes hypoxia. Such phenomena are sure to affect other biochemical parameters of blood, including those related to oxidative processes.

Glutathione part of the antioxidant system plays an important role in the antiradical and anti-peroxide protection of cells [22, 23]. Well coordinated func- tioning of all its components (GSH, GPO, and GR) promotes the optimal level of peroxide compounds and preservation of antioxidant homeostasis. Nonenzymatic characteristics of the antioxidant status are the amounts of GSH, lipid hydroperoxides, TBARS, which accumulation can be the way to characterize the intensity of LPO. Literature data show that the level of GSH, activity of GPO, GR, glutathione-S-transferase (GST) can be used as criteria to assess the toxic effects of xenobiotics of different chemical nature [22, 24].

As seen on Fig. 2, the content of reduced glutathione firstly - at the 15 th minute of the experiment (E1 group) - increased by 17.6\% $(P<0.05)$, compared with control, but already in the next time interval, in a half an hour after CPF exposure, we observed the opposite phenomenon: this index declined by $44 \%(P<0.05)$ (in E2 group), compared with one in control hemolisates.

The initial increase of GSH content may indicate its protective effect on the proteins and cellular structures against the damage by CPF-caused oxidative stress. In addition, glutathione may intensify the inactivation of hydroperoxides and other toxic oxidation products.

In its turn, the GSH decrease at $30 \mathrm{~min}$ after toxicant exposure could be associated with the presence of a larger amount of free radicals produced by CPF, and it may indicate increased consumption of GSH in detoxification reactions. Thus, it has been assummed that the observed decrease of GSH in erythrocytes can be attributed to its conjugation to the CPF metabolism products and to involvement of reactive oxygen species (ROS), which

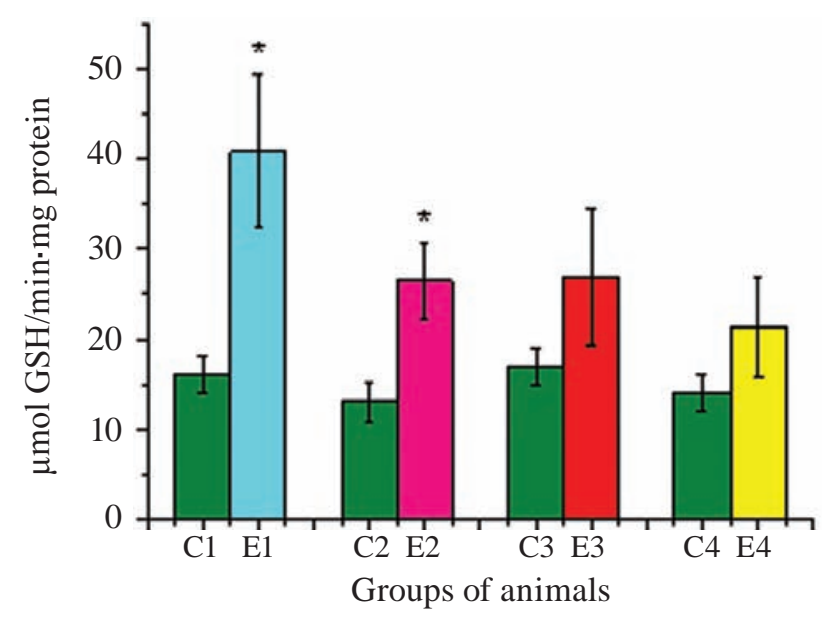

Fig. 2. GSH content in the red blood cells of rats during 1 hour after CPF exposure 
production is reported to be induced by toxic effects of OPs on biological systems [25]. Notably, GSH is the main antioxidant in the red blood cells; it acts as a coenzyme in the recovery of methemoglobin to functionally active hemoglobin. In addition, it participates in detoxification of a large number of toxic compounds and xenobiotics, and also $\mathrm{H}_{2} \mathrm{O}_{2}$ and lipid hydroperoxides formed in the reactions between reactive oxygen species and unsaturated fatty acids of erythrocyte membrane [23]. GSH acts as a reducing agent and vital substance in detoxification and provides antioxidant protection in the aqueous phase of cellular systems. GSH antioxidant activity is provided by the thiol group of its cysteine residue. Like ascorbic acid, GSH can directly reduce a number of ROS and is oxidized to GSSG in this process. GSH also acts as substrate and co-substrate for many essential enzymes, such as GPO and GST.

It is known that the alterations of GPO enzyme complex system occur in conditions of oxidative stress. In red blood cells with high rate of hydrogen peroxide formation, GPO most actively participates in its neutralization. In its turn, along with the decrease in the GPO activity, erythrocyte hemolysis increases due to the action of hydrogen peroxide and lipid peroxides.

As our study has shown, the most prominent increase in the GPO activity (Fig. 3) was observed 15 min after CPF exposure, i.e. in the E1 group, where it exceeded the control values 2.5 times $(P<0.05)$. A significant $(P<0.05)$ two-times increase in the activity of this enzyme, compared to the control group, occurred in group E2, i.e., measured 30 min after CPF exposure. The prominent increase in GPO activity at the first $30 \mathrm{~min}$ after intoxication, obviously, not only leads to the reduction of hydrogen peroxide to water, but also substantially prevents the accumulation of $\mathrm{OH}^{-}[26]$.

GR catalyzes the reduction of oxidized glutathione with the participation of NADPH or NADH as donors of protons and electrons. This means that the content of GSH depends on its activity. As shown at Fig. 4, GR activity significantly increases by $26.8 \%(P<0.05)$, compared with the control, only at the first minutes after intoxication (E1). Perhaps, the increased level of GR activity at the first $15 \mathrm{~min}$ of the experiment was a compensatory response of blood cells to high concentrations of ROS.

It should also be noted that GR activity among many reasons may depend on NADPH and is inhibited by the accumulation of oxidized nucleotide form

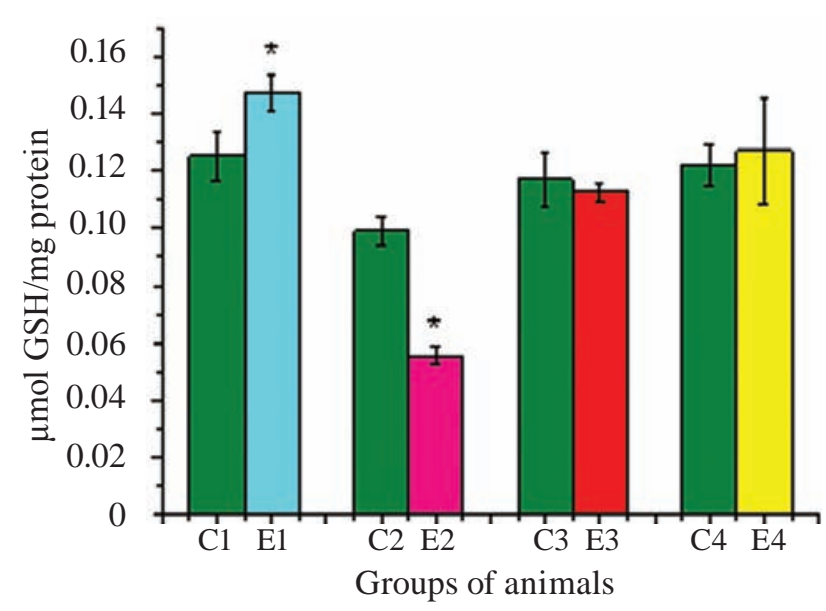

Fig. 3. GPO in the red blood cells of rats during 1 hour after CPF exposure

(NADP). The reduced nucleotide form (NADPH + $\mathrm{H}^{+}$) is formed in hexose monophosphate shunt (pentose cycle) and provides $\mathrm{N}^{+}$for the regeneration of GSH from GSSG with GR.

Free radical oxidation reactions result in production of large amounts of lipid peroxidation products, including lipid hydroperoxides (LPO primary products). Lipid hydroperoxides are unstable substances and are easily converted to a number of more stable secondary oxidation products: aldehydes, ketones, low molecular weight acids (formic, acetic, butyric). These substances are toxic to cells and lead to general disruption of membrane function and metabolism. Splitting of a hydrogen atom from molecules of polyunsaturated fatty acids (such as arachidonic acid) forms conjugated dienes. LPO products also include peroxide radicals, MDA

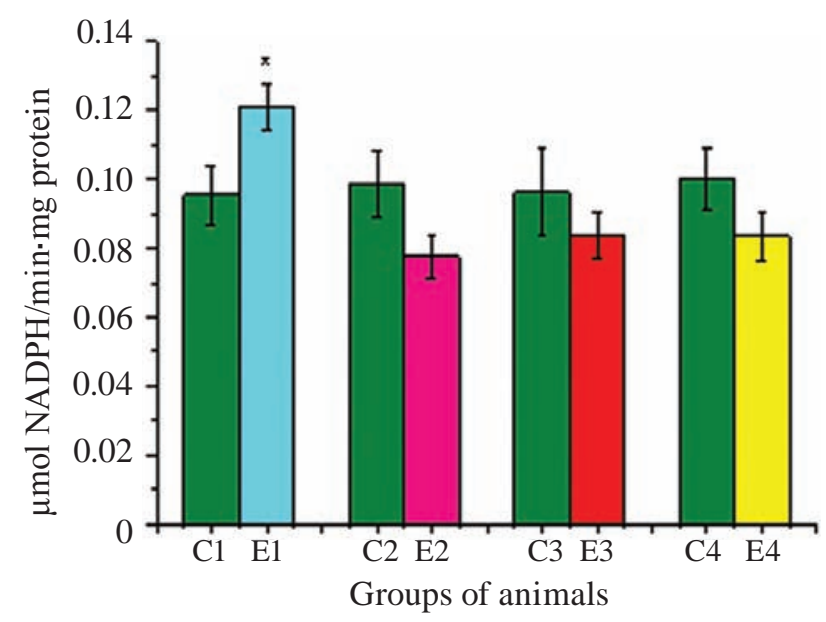

Fig. 4. GR activity in the red blood cells of rats during 1 hour after CPF exposure 
(secondary product of LPO), formed in the oxidative degradation of lipids, and Schiff bases. For evaluation of the LPO intensity, quantitative determination of TBARS and lipid peroxides content is often used. The data (Fig. 5) show that the content of TBARS increased significantly (by $45 \%, P<0.05$ ) in the group E4, i.e., one hour after $\mathrm{CPF}$ exposure to the experimental rats.

In turn, the content of lipid hydroperoxides was significantly higher in erythrocytes of exposed animals than of intact ones, after 30 and 45 min: by 80\%, $(P<0.05)$ and $139 \%(P<0.05)$, respectively (Fig. 6).

In general, summing up the dynamics of changes in both enzymatic and non-enzymatic parameters of glutathione system in rat erythrocytes at different time intervals after CPF intoxication, one could argue that the most prominent deviations in almost all of the studied parameters occurred in groups E1 and E2, i.e., in the first 15-30 min after the exposure. This should be explained by close and bidirectional relationships between physiological and biochemical effects of acute CPF toxicity, in particular, inhibition of choline-dependent processes, hypoxia, oxidative stress, cytotoxicity, etc. On the one hand, CPF is known for causing oxidative stress in various tissues, accompanied by disruption of intracellular balance between ROS and antioxidants (cell RedOx status), along with activation of ROS formation, increase of free radical and peroxidation processes, and destruction of cellular structures. The latter is largely due to the hydrophobicity of the CPF

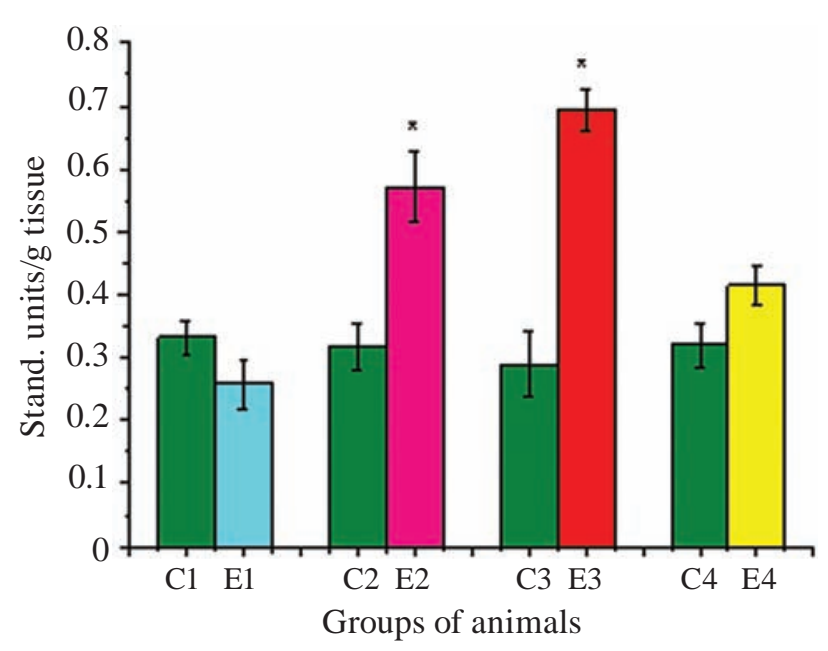

Fig. 5. TBARS content in the red blood cells of rats during 1 hour after CPF exposure molecules and their ability to build in the cell lipid bilayer membranes and penetrate into the cytoplasm [16]. On the other hand, CPF intoxication also leads to hypoxia that directly affects blood cells, including red blood cells. However, alterations in the functional state of the erythrocytes antioxidant system also cause hypoxia via violations in mechanisms of oxygen disposal and transport.

Identified changes in parameters of pro/antioxidant system under the effect of CPF exposure emphasize the need for more profound and complex studies to investigate intracellular signalling events, toxic effects on components of the mitochondrial transport chain, proteins, lipids, DNA, RNA, etc.

We have found that acute intoxication with $50 \mathrm{mg} / \mathrm{kg}$ CPF during the first hour after exposure caused: (1) Rapid, progressive, linear decrease of cholinesterase activity in blood serum during the first 45 minutes after poisoning: by $42.5 \%$ after 15 min (E1), by $65.5 \%$ after 30 min (E2), by $81.1 \%$ after 45 min (E3), compared with control groups of intact animals. At 60 min (E4), the activity was higher than at previous time point, but still remained significantly lower (by $54.6 \%$ ) than in control group. (2) An increase in GSH by $17.6 \%$, compared with control, after 15 min (E1), and subsequent decrease of this parameter by $44 \%$ after 30 min (E2); (3) A sharp increase in GPO activity in erythrocytes hemolisate in the first half an hour of the experiment, compared with control: 2.5 times after $15 \mathrm{~min}$ (E1), and 2 times after 30 min (E2); (4) An increase in GR activity by $26.8 \%$ after 15 min (E1), compared

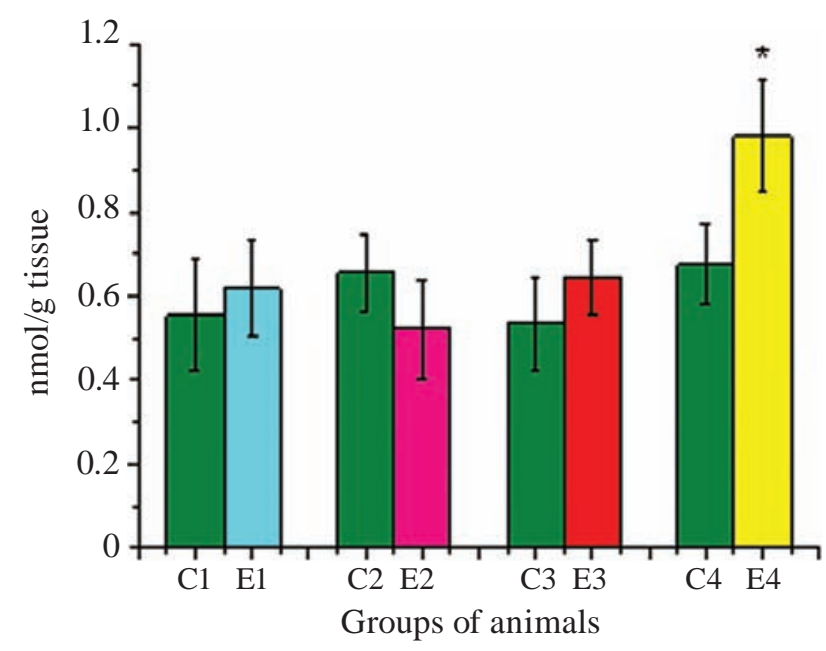

Fig. 6. Lipid hydroperoxides content in the red blood cells of rats during 1 hour after CPF exposure 
with control; (5) An increase in the TBARS by $45 \%$ after 60 min (E4), and in lipid hydroperoxides: by $80 \%$ after 30 min (E2), by 139\% after 45 min (E3), compared with control values.

Therefore, the detected changes show that, already at first minutes after the exposure, CPF caused not only cholinesterase inhibition, but also alterations in glutathione system and LPO processes in rat blood. This confirms that biochemical toxicity mechanisms of OPs, and particularly CPF, are connected with pro/antioxidant reactions and processes. Moreover, the obtained results may become a part of the background for possible construction of pathways and methods for pharmacological correction and protection of cytotoxic damage caused by CPF or analogous compounds. Successful implementation of these tasks becomes possible via comprehensive study of the relationship between pro- and antioxidant processes in different systems and tissues, and other molecular mechanisms of adverse effects of organophosphorus poisons, focusing on the role of antioxidant system, LPO and anticholinesterase phenomena.

\section{ЗМІНИ ГЛУТАТІОНОВОЇ СИСТЕМИ ТА ПЕРОКСИДНОГО ОКИСЛЕННЯ ЛІПІДІВ У КРОВІ ЩУРІВ ПІД ВПЛИВОМ ХЛОРПІРИФОСУ ПРОТЯГОМ ПЕРШОЇ ГОДИНИ ПІСЛЯ ЙОГО ВВЕДЕННЯ}

\section{В. П. Росаловський, С. В. Грабовська, Ю. Т. Салига}

Інститут біології тварин НААН, Львів, Україна; e-mail: ros.volodymyr@gmail.com

Хлорпірифос - _ високотоксична фосфорорганічна сполука, яка широко використовується в багатьох інсектицидах. Разом 3 антихолінестеразною дією, вплив хлорпірифосу на організм може реалізовуватись за допомогою інших біохімічних механізмів, у тому числі через порушення прооксидантно-антиоксидантного балансу та індукування вільнорадикального оксидативного стресу. Особливості виникнення і перебігу цих явищ до кінця не з'ясовано. Метою роботи було дослідити вплив хлорпірифосу на основні параметри глутатіонової системи антиоксидантного захисту та процеси пероксидного окислення ліпідів у крові щурів у часовій динаміці (впродовж однієї години) одразу після введення хлорпірифосу дослідним тваринам. Встановлено, що одноразове введення щурам хлорпірифосу в дозі 50 мг/кг спричиняло, поряд 3 лінійним зниженням бутирилхолінестеразної активності, зростання активності глутатіонпероксидази та глутатіонредуктази, а також змінювало рівень відновленого глутатіону, ТБК-активних продуктів та гідропероксидів ліпідів. Найвагоміші зміни досліджуваних показників мали місце на 15- та 30-й хвилинах після введення хлорпірифосу в організм.

К л ючов і слов а: система антиоксидантного захисту, глутатіонова система, глутатіонпероксидаза, глутатіонредуктаза, відновлений глутатіон, пероксидне окислення ліпідів, кров, хлорпірифос, щури.

\section{ИЗМЕНЕНИЯ ГЛУТАТИОНОВОЙ СИСТЕМЫ И ПЕРОКСИДНОГО ОКИСЛЕНИЯ ЛИПИДОВ В КРОВИ КРЫС ПОД ВЛИЯНИЕМ ХЛОРПИРИФОСА В ТЕЧЕНИЕ ПЕРВОГО ЧАСА ПОСЛЕ ЕГО ВВЕДЕНИЯ}

\section{В. П. Росаловский, С. В. Грабовская, Ю. T. Сальгга}

\author{
Институт биологии животных \\ НААН, Львов, Украина; \\ e-mail: ros.volodymyr@gmail.com
}

Хлорпирифос - высокотоксичное фосфорорганическое соединение, широко используемое во многих инсектицидах. Наряду с антихолинэстеразным действием, влияние хлорпирифоса на организм может реализовываться с помощью других биохимических механизмов, в том числе из-за нарушений прооксидантно-антиоксидантного баланса и индуцирования свободнорадикального оксидативного стресса. Особенности возникновения и протекания этих явлений до конца не выяснены. Целью работы было исследовать влияние действия хлорпирифоса на основные параметры глутатионовой системы антиоксидантной защиты и процессов пероксидного окисления липидов в крови крыс, во временной динамике (в течение одного часа) после введения хлорпирифоса подопытным животным. Установлено, что однократное введение крысам хлорпирифоса в дозе 50 мг/кг вызывало, наряду с 
линейным снижением бутирилхолинэстеразной активности, рост активности глутатионпероксидазы и глутатионредуктазы, изменение уровня восстановленного глутатиона, ТБК-активных продуктов и гидропероксидов липидов. Самые значительные изменения исследуемых показателей наблюдались на 15- и 30-й минутах после введения хлорпирифоса в организм.

Ключевы е слова: система антиоксидантной защиты, глутатионовая система, глутатионпероксидаза, глутатионредуктаза, восстановленный глутатион, пероксидное окисление липидов, кровь, хлорпирифос, крысы.

\section{References}

1. Needham L. L. Assessing exposure to organophosphorous pesticides by biomonitoring in epidemiologic studies of birth outcomes. Environ. Health Persp. 2005;113(4):494-498.

2. Salyha Y. Biological effects assessment of chlorpyrifos and some aspects of its neurotoxicity. Visnyk Lviv University. Biology Series. 2010;54:3-14.

3. Ambali S. F., Ayo J. O., Esievo K. A. Hemotoxicity Induced by Chronic Chlorpyrifos Exposure in Wistar Rats: Mitigating Effect of Vitamin C. Vet. Med. Int. 2011;2011:1-7.

4. Salyha Y. Toxic effect of chlorpyrifos on hippocampal neurons in vitro. Animal Biology. 2010;12(1):163-168.

5. Eaton D. L., Daroff R. B., Autrup H., Bridges J., Buffler P., Costa L. G., Coyle J., McKhann G., Mobley W. C., Nadel L., Neubert D., SchulteHermann R., Spencer P. S. Review of the toxicology of Chlorpyrifos with an emphasis on human exposure and neurodevelopment. Crit. Rev. Toxicol. 2008;38(2):1-125.

6. Salyha Y. Chlorpyrifos leads to oxidative stressinduced death of hippocampal cells in vitro. Neurophysiology. 2013;45(3):193-199.

7. Tripathi S., Suzuki N., Srivastav A.K. Response of serum minerals (calcium, phosphate, and magnesium) and endocrine glands (calcitonin cells and parathyroid gland) of Wistar rat after chlorpyrifos administration. Microsc. Res. Tech. 2013;76:673-678.

8. Elsharkawy E. E., Yahia D., El-Nisr N. A. Sub-chronic exposure to Chlorpyrifos induces hematological, metabolic disorders and oxidative stress in rat: Attenuation by glutathione. Environ. Toxicol. Pharmacol. 2013;35(2):218-227.
9. Jasna J. M., Anandbabu K., Bharathi S. R., Angayarkanni N. Paraoxonase enzyme protects retinal pigment epithelium from chlorpyrifos insult. PloS One. - 2014;9(6):1-10.

10. Pauer G. J., Sturgill G. M., Peachey N. S., Hagstrom S. A. Protective effect of paraoxonase 1 gene variant Gln192Arg in age-related macular degeneration. Am. J. Ophthalmol. 2010;149(3):513-522.

11. Pandey K. B., Rizvi S. I. Markers of oxidative stress in erythrocytes and plasma during aging in humans. Oxid. Med. Cell Longev. 2010;3(1):212.

12. Morris G., Anderson G., Dean O., Berk M., Galecki P., Martin-Subero M., Maes M. The glutathione system: a new drug target in neuroimmune disorders. Mol. Neurobiol. 2014;50(3):1059-1084.

13. Lushchak V. I. Glutathione homeostasis and functions: potential targets for medical interventions. J. Amino Acids. 2012;2012:1-26.

14. Raftos J. E., Whillier S., Kuchel P. W. Glutathione synthesis and turnover in the human ery throcyte: alignment of a model based on detailed enzyme kinetics with experimental data. J. Biol. Chem. 2010;285(31):23557-23567.

15. Karpyshtshenko A. Medical laboratory technologies and diagnostics: Handbook. St. Petersburg: Intermedica, 1999. 656 p. (In Russian).

16. Moin V. A simple and specific method for glutathione peroxidase activity assessment in erythrocytes. Lab. Delo. 1986;(12):724-727. (In Russian).

17. Carlberg I. Purification and characterization of the flavoenzyme glutathione reductase from rat liver. J. Biol. Chem. 1975;250(14):5475-5480.

18. Hissin P. J., Hilf R. A. A fluorometric method for determination of oxidized and reduced glutathione in tissues. Analyt. Biochem. 1976;74(1):214-226.

19. Vlizlo V. V., Fedoruk R. S., Ratych I. B. Laboratory methods of research in biology, animal husbandry and veterinary medicine. Lviv: Spolom, 2012. 764 c.(In Ukrainian).

20. Korobeynikova E. A modification of lipid peroxidation products assessment in the reaction with thiobarbituric acid. Lab. Delo. 1989;(7):8-9. (In Russian).

21. Lowry O. H., Rosebrough N. J., Farr A. L., Randall R. J. Protein measurement with the Folin 
phenol reagent. J. Biol. Chem. 1951;193(1):265275.

22. Baraboy V. Bioantioxidants. Kyiv: Knyha plus, 2006. 462 p. (In Russian)

23. Salyha N. Activity of the glutathione system of antioxidant defense in rats under the action of L-glutamic acid. Ukr. Biokhim. Zhurn. 2013;85(4):40-47. (In Ukrainian).

24. Khaybullina Z. R., Vahidova N. T. Parameters of peripheral blood under experimental acute hypoxia. Chelyabinsk: Dva Komsomoltsa. 2012. P. 24-29. (In Russian).
25. Salyha Y., Rosalovskyi V. To the study of some parameters of antioxidant defense system and lipid peroxidation in blood of rats under the toxic influence of chlorpyrifos. Ukr. Morphol. Almanac. 2012;10(3):94-95. (In Ukrainian).

26. Beloqui O., Cederbaum A. J. Prevention of microsomal production of hydroxyl radicals, but not lipid peroxidation, by the glutathioneglutathione peroxidase system. Biochem. Pharmacol. 1986;35(16):2663-2669.

Received 12.02.2015 